Chicago-Kent College of Law

Scholarly Commons @ IIT Chicago-Kent College of Law

January 1994

\title{
Authority, Community and the Civil Law Commentary: An Example From German Competition Law
}

David J. Gerber

IIT Chicago-Kent College of Law, dgerber@kentlaw.iit.edu

Follow this and additional works at: https://scholarship.kentlaw.iit.edu/fac_schol

Part of the Antitrust and Trade Regulation Commons, Comparative and Foreign Law Commons, International Trade Law Commons, and the Law and Economics Commons

\section{Recommended Citation}

David J. Gerber, Authority, Community and the Civil Law Commentary: An Example From German Competition Law, 42 Am. J. Comp. L. 531 (1994).

Available at: https://scholarship.kentlaw.iit.edu/fac_schol/213

This Article is brought to you for free and open access by the Faculty Scholarship at Scholarly Commons @ IIT Chicago-Kent College of Law. It has been accepted for inclusion in All Faculty Scholarship by an authorized administrator of Scholarly Commons @ IIT Chicago-Kent College of Law. For more information, please contact jwenger@kentlaw.iit.edu, ebarney@kentlaw.iit.edu. 
DAVID J. GERBER

\section{Authority, Community and the Civil Law Cornmentary: An Example From German Competition Law}

A Review Essay on GWB: Kommentar zUM Kartellgesetz. Edited by Ulrich Immenga \& Ernst-Joachim Mestmäcker. Munich: Verlag C.H. Beck München 1992 (2d ed.). Pp. 2558.

People usually read books about law in order to find out what is in them. Most books, in fact, can only be read on this level, because their only role is as a source of information. Occasionally, however, a book plays a significant enough role within a legal system that it can also be read at a second level. The commentary on German competition law edited by Ulrich Immenga and Ernst-Joachim Mestmäcker (the Immenga/Mestmäcker commentary) is such a book. It is an exceptionally valuable source of information about German and, to a lesser extent, European Community competition law, but it has also been a powerful source of authority within the German competition law system since the first edition was published in 1981. ${ }^{1}$ To "read" it at a second level thus provides insights into the dynamics of that system. This essay explores the potential value of "reading" the work both as a source of information and as part of the competition law system.

\section{The Commentary as a Source of Information}

As a source of information about German competition law, the book is extraordinary. With more than 2600 large, tightly-filled pages (including indexes and appendix) it purports to cover all issues

David J. Gerber is member Board of Editors, Professor of Law, Chicago-Kent College of Law, Illinois Institute of Technology.

1. The concept of "system" that I am using here deserves a brief comment. I am using it to refer to the complex of norms, practices and institutional arrangements that relate to a specified set of objectives - here, the protection of competition from private restraints. This usage is significantly more specific than the normal use of the term to refer to an entire "system" of law (e.g., "the civil law system") and it is more analytically valuable, because it focuses analysis on the ways in which texts, arrangements and decisions involving particular goals relate to each other. See also Gerber, "The Transformation of European Community Competition Law?," 35 Harv. Int'l L. J. 97 (1994). 
of any significance in German competition law. On every conceivable topic there is detailed discussion of the relevant issues plus extensive and usually exhaustive references to the relevant legal literature. It also contains a good index and an appendix with the full text of many (13) documents that are important for understanding the operations of the German competition law system.

As if it were not enough to cover German competition law this thoroughly, the book also contains much material on European Community competition law. This material is generally included where it relates to a particular substantive or procedural issue of German competition law, although the European Merger Control Regulation is treated independently and in its entirety. Community competition law received little coverage in the first edition, but its growing importance made the inclusion of this material virtually mandatory for the second edition, and it represents a valuable improvement.

The work is in the form of a traditional civil law commentary. After a rather austere introduction, the material is organized as a series of commentaries on the language of the individual sections (1109) of the Gesetz gegen Wettbewerbsbeschränkungen (GWB) - the statute on which the German competition law system is based. Twelve authors participated in writing the text, with each responsible for a particular section or group of sections.

For a reader who knows how the GWB is constructed, this packaging of the material is as good as any, and probably superior to most. For the uninitiated - whether foreign observer or German non-specialist, however, this form creates problems. One who does not already know the structure of the GWB will have some difficulty using the commentary, because that structure locates the information. ${ }^{2}$ Even with a good index and other aids such as a "quick overview of key words" (Schnellübersicht über wichtige Stichwörter) on the dust-jacket flap, such a reader will sometimes have problems seeing how the information fits together. Moreover, she is unlikely to feel confident that she has located all the relevant information.

Nevertheless, the structure of the GWB is not overly complex, and thus this obstacle is less serious than it is in the context of a more complicated statute such as the German Civil Code (Bürgerliches Gesetzbuch or BGB). In order to use a BGB commentary effectively, one must have studied the structure of the code intensively, but that is not true with regard to the competition law statute.

The information provided by this commentary is accurate, reliable and detailed. German competition law has become too complicated for one or even two or three authors to provide this level of

2. For discussion of the "efficiency" function of "relative space" in a civil law' commentary, see Rheinstein, "The Approach to German Law," 34 Indiana L. J. 546, 56063 (1959). 
depth and completeness, and thus it was achieved by entrusting individual sections to experts in the relevant legal areas. Each section also bears the name of its author, providing an additional incentive for authors to display the full range of their knowledge and acumen.

The style is also that of the traditional civil law commentary. The authors present their material as authoritative interpreters of the text, ${ }^{3}$ as if the voice of the text were speaking through its chosen interpreters. ${ }^{4}$ The implicit message is that the commentary is playing an indispensable role in giving meaning to the statute. This style tends to resist open subjectivity and to discourage the expression of doubt, and this may be one of the reasons that the authors sometimes do not clearly indicate the extent to which their language reflects little more than their personal views.

This can be a problem for the non-specialist reader, who may sometimes have difficulty recognizing what is well-established general opinion and what represents the particular expert's "line" of interpretation. Even system insiders may have difficulty distinguishing between generally accepted interpretations and personal preferences on issues with which they are not familiar.

As a source of information, therefore, the Immenga/Mestmäcker commentary is an exceptionally valuable work. Complete, accurate and authoritative, it can provide answers for virtually all questions that have been posed about German competition law. Outsiders to the system will have more difficulty using this book than will insiders, but there is simply no better source of information for either group.

\section{The Commentary as a Source of Authority}

So much for reading the Immenga/Mestmäcker commentary as a source of information; reading it as part of the system is more difficult and more speculative, but it may be no less valuable. Here our concern will be with the book as an influence on the competition law system as well as a reflection of that system. The two are connected.

Assessing a book's influence is always hazardous. There will always be some who say that any assessment is too positive and others who say that it is not positive enough, and there is seldom an "objective" means of supporting a particular formulation. Nevertheless, I think it is fair to say that the Immenga/Mestmäcker commentary is widely recognized as a, perhaps even the, dominant source of secon-

3. They are introduced as "Bearbeiter" of the materials, i.e., those who "work" the material.

4. This style is similar to that traditionally used in German court opinions. For discussion, see, e.g., Weyrauch, "The Art of Drafting Judgments: A Modified German Case Method," 9 J. Legal Ed. 311 (1956). 
dary authority within German competition law. ${ }^{5}$ It is cited with great frequency and respect by academics, judges and practitioners, and where it supports an argument, that argument is - almost invariably - greatly strengthened. Moreover, if an individual or law firm has but one detailed book on competition law, it will typically be this one. ${ }^{6}$

But why does it enjoy such respect? What are the sources of authority? What roles does the commentary play? And what do these roles reveal about the competition law system itself?

\section{A. Authority and Text}

The format of the commentary itself generates authority. The commentary is presented as part of the traditum of the text - i.e., the "package" of material to be transmitted with the text and understood as an extension of it. ${ }^{7}$ As such, it is an interpretation that becomes linked with - even integral to - the text, and it bespeaks an assumption that the text will henceforth be read in the light of such interpretations.

The commentary's "voice-of-the-statute" style strengthens this impact. "Knowledge" is presented with aplomb and the claim of authority, and this in itself evokes confidence in the text. While an insider's reading of a particular passage might reveal points of equivocation, most readers will experience the self-assured presentation of positive knowledge.

The text's scope, depth and detail further contribute to this aura of authority. The commentary's information is interwoven with the message: "I can answer virtually all competition law questions that can be answered." The Immenga/Mestmäcker commentary presents itself as a definitive reference work, and this presentation itself generates respect: the reader knows she will probably not need to look much further for her answer.

In addition to its psychological impact, this "completeness" factor gains force from the place and roles of competition law in Germany. German competition law is important, especially for certain types of enterprises, but its importance seldom warrants shelves of books. Except for a small group of competition law specialists, German practitioners, bureaucrats and judges are not likely to possess more than

5. It is important to note here that legal doctrine is a particularly powerful force within German law. The most illuminating study is still that of Josef Esser, Grundsatz und Norm in der richterlichen Fortbildung des Privatrechts (4th ed. 1990), esp. pp. 306-27.

6. There are several other commentaries on German competition law. For a current (1993) list, see Fritz Rittner, Wettbewerbs- und Kartellrecht XXXVII (4th ed. 1993).

7. For discussion of the process of transmitting texts and associated interpretations within an intellectual tradition, see Edward Shils, Tradition 140-61 (1981). 
one serious reference work on competition law, ${ }^{8}$ and thus they are likely to seek a work that purports to answer their questions as completely as possible. By corresponding to the operational characteristics of the system, therefore, the text's completeness undergirds its own authority.

This relationship between the commentary's structure and the characteristics of the system has many additional dimensions. For example, the commentary format is closely linked to the intellectual methods and modes of thought within the system. The working assumption in German competition law is that most questions can be answered at the level of abstraction used in this type of commentary. In brief, the commentary identifies principles governing the interpretation and application of the statutory language and discusses the issues that have arisen in regard to the interpretation and application of these provisions. Normally, this is all that one is expected to know when answering a question about competition law. In most situations, therefore, there is no incentive to go beyond the commentary and read the cases and monographs in the area oneself. ${ }^{9}$ This mode of operation makes it especially important for the legal professional to have a definitive commentary, and a commentary that acquires that status gains, in turn, the additional force and appeal of practical exclusivity.

The role of the GWB in the German competition law system strengthens the impact of the commentary form. The GWB created the system, and the system continues to be - quite literally - based on it. Virtually everything that happens in the system is tied to the specific language of the statute, drawing both structure and authority from that language.

This "bonding" between text and operating system functions at two levels. First, as is common in civil law systems, the language of the statute tends to be the starting-point and framework for thinking about the substantive law of the system. The conduct norms and the principles governing their application are located in either the text or the authoritative interpretations attached to it. That text thus structures thought within the system by providing both its concepts and its grammar.

On a second level, the GWB structures the institutions and procedures of the system. For example, it establishes the Federal Cartel Office (FCO - the independent office that applies and enforces German competition law) specifies its general authority and specific pro-

8. Many may have nothing more than a general treatise on competition law, such as that by Wernhard Möschel. See Wernhard Möschel, Recht der Wettbewerbsbeschränkungen (1983).

9. The next step, if one chooses to go further, is to read the decisions as published in the leading journal in the area, Wirtschaft und Wettbewerb. 
cedural prerogatives and designates the situations in which private actions are permitted.10 In this respect, the structuring role of the GWB is even more central than in more traditional areas of law, because the GWB (unlike, for example, the German Civil Code) provides not only substantive, but also procedural and institutional structuring.

The entire competition law system is thus organized according to the language of this one statute, and a commentary on that language gains force through the immediacy of its relationship to all aspects of the system. It presents information and opinion in a form that is directly linked to the institutional components of the system as well as its intellectual and procedural frameworks. As a consequence, its concepts serve as the constant frame of reference for all discourse, and it penetrates the system in a way that a treatise - which is organized according to principles external to the language of the text - cannot.

\section{B. Individual Authority}

But these factors apply generally to any detailed commentary, and the question remains: What makes this particular commentary especially powerful? Here both individual and "collective" authority are important.

One component of the authority of the Immenga/Mestmäcker commentary derives from the individual reputations of the respective contributors. With one exception (a judge) all are either law professors specializing in competition law or high officials of the Federal Cartel Office. Each is a respected authority in his own right in the specific area about which he is writing; ${ }^{11}$ the authors write not merely as competition law specialists, but as acknowledged experts in particular areas of competition law. By placing the authors' names prominently at the bottom of the pages of the individual sections for which they are responsible, the book emphasizes the importance of individual authority.

This emphasis on the specialized knowledge of authors has links to the principle of specialization that is familiar in the German (and most civil law) legal systems. ${ }^{12}$ This principle places a high value on the specialized knowledge of legal "authorities" such as courts and other authoritative decision-makers. Appeals courts, for example,

10. For a recent discussion in English of the FCO and its operations, see Fiebig, "The German Federal Cartel Office and the Application of Competition Law in Reunified Germany," 14 U. Penn. J. Int'l Bus. L. 373 (1993).

11. For example, Wernhard Möschel is responsible for the section relating to abuse of a market-dominating position, and this is an area in which he is an acknowledged expert and the author of books and articles.

12. For examples and discussion, see generally Arthur T. von Mehren \& James R. Gordley, The Civil Law System 126-34 (2d ed. 1977). 
typically are divided into chambers that hear all cases involving particular issuess (e.g., competition law or intellectual property rights). This allows - indeed, requires - judges to become expert in that substantive law area. A commentary can thus gain authority by paralleling the characteristics of acknowledged sources of authority within the system and corresponding to the expectations attached to such sources of authority. ${ }^{13}$

\section{Authority and Community}

Yet there is more involved than the reputations of the individual authors. What may be called "collective" or "community" authority is also crucial. The book derives much of its force from its relationship to, and roles within, the leadership community of German competition law. This is a book written by key representatives of that community, and thus its composition and dynamics are critical to our inquiry. Who belongs to it? How does it function?

Here the concept of system that I have been using plays an important analytical role. Much that is happening in German competition law is difficult to discern unless one sees the myriad of decisions and norms involving competition law as part of a distinct system. ${ }^{14}$ This system is autonomous in the sense that its norms, institutions and discourse operate self-reflexively - i.e., as parts of a largely selfcontained unit. ${ }^{15}$ Other components of the German legal system form the backdrop - as influential as that may be in some cases - in front of which this competition law system operates.

Recognizing the existence and autonomy of this system makes it possible, in turn, to perceive a leadership community within it. ${ }^{16} \mathrm{We}$ discover that the decisions that operate the system are made almost exclusively by a relatively small group of individuals who play roles within this community. ${ }^{17}$ One potentially useful way of portraying this system would identify the GWB, its authoritative interpretations and the institutions of the system as its structural components (skeleton, sinews, etc.) and this leadership community as its vital organs.

13. Interestingly, specialization often has been considered relatively unimportant for legal practitioners, although that is changing in some parts of the civil law world. See, e.g., Richard W. Abel \& Philip S.C. Lewis, eds., Lawyers in Society, Vol. 2: The Civil Law World 18-22 (1988).

14. The concept of legal "regimes" that has been developed by political scientists such as Robert Keohane may also be valuable in describing and analyzing these relationships. For general discussion of regime theory, see, e.g., Young, "International Regimes: Toward a New Theory of Institutions," 39 World Pol. 104 (1986).

15. In recent years legal sociologists such as Günther Teubner have added significantly to our understanding of the self-reflexiveness of legal systems. See, e.g., Günther Teubner, Law as an Autopoietic System (1993).

16. For related discussion of "leader groups," see Max Rheinstein, Max Weber on Law and Society 198-223 (1954).

17. While the existence of these relationships is well known to system insiders, there is very little mention of this aspect of the system in the legal literature. 
The contours of this community are relatively distinct. ${ }^{18}$ It includes the leading officials of the FCO, the judges in the chambers of the courts responsible for reviewing competition law decisions, 19 professors (primarily law professors, but also some economists) who are active in competition law matters, and many of the practitioners who write in the area. ${ }^{20}$ Virtually all decisions of importance in German competition law are made, or heavily influenced, by the hundred or so members of this group. ${ }^{21}$

In this context, a commentary can hardly be influential unless it emanates from leading representatives of this community, and this the Immenga/Mestmäcker commentary does. Its list of authors consists of highly respected members of each of the sub-groups within the community (other than the practitioners group) with law professors and high officials of the FCO predominating. Note that for these purposes academicians, administrative officials, judges and practitioners all belong to the same community, participate in the same projects and speak the same "language." There is no separation between academic and "practice-based" discourse.

What, however, does membership entail? How does one gain membership? And who has what sorts of influence and power within the system? This is not the place for a full discussion of these issues, but we need to know enough about them to inform our "reading" of the Immenga/Mestmäcker commentary.

Membership criteria are central factors in the dynamics of any community, and in the leadership community of the competition law system, membership revolves around scholarship. The publication of scholarly work in competition law is a virtual prerequisite to membership, and members must continue to publish such work in order to maintain their influence within the community. In most cases this means publishing articles and books, but judicial and administrative opinions may be treated as scholarly work for these purposes. ${ }^{22}$ This, in turn, creates an incentive for judges and administrators to write

18. In the United States, in contrast, it would be difficult to define a leadership community in the area of antitrust, and it certainly would not have the same characteristics or relationship to the system as one finds in Germany.

19. Appeals from decisions of the FCO are heard by the Cartel Chamber (Kartellsenat) of the Kammergericht in Berlin, where the FCO is located. Decisions of that court may generally be appealed to the Cartel Chamber of the Federal Supreme Court (Bundesgerichtshof). Appeals of the much rarer private competition law actions may be heard by other appeals courts, but such decisions tend to be of marginal importance for the operation of the system.

20. This is one of the major incentives for practitioners to pay as much attention as they often do to publishing in the area.

21. The figure of one hundred is used merely to indicate the order of magnitude involved. One could also defend the addition of another fifty or so.

22. The FCO operates to a significant degree according to judicial procedures and principles. For discussion, see Rittner, "Das Ermessen der Kartellbehörde," in Festschrift für Arthur Kaufmann 307 (1972). 
opinions that, are relatively "scholarly" 23 and reinforces the uniformity of discourse within the system.

This emphasis on scholarship as a criterion for membership is associated - as both cause and effect - with the powerful role of law professors in German competition law. In a community that is based on scholarship, professors are likely to have power, because scholarship is a principal part of what they are paid to. They tend to have the time and the resources (e.g., research assistants) to write the most as well as the opportunities to influence decisions about what is published and who is invited to the conferences which are often associated with publication.

As the product of key representatives of this community, the Immenga/Mestmäcker commentary becomes associated with its collective authority. Here the concept of communis opinio plays a role in the dynamics of the system. According to German (and most continental) legal thought, the operative "law" at a particular time is what the relevant "community" of legal scholarship says it is (i.e., it represents the collective opinion of the community). One automatically looks, therefore, to the "dominant opinion" (herrschende Meinung) of the community for guidance, and most decision-makers will in most cases follow that opinion in their decisions. ${ }^{24}$ Where, as here, a commentary represents key leaders within the community, its contents easily become identified with the judgments of the community as a whole. They "wear the mantel" of the community's "dominant opinion," 25 and for the reader who does not wish to expend the time and resources needed to explore the full range of opinion on an issue this is likely to be determinative. It is another example of how a commentary can gain force by "tracking" patterns of thought within the system.

\section{More Than Just Authority: Commentary and Community}

The Immenga/Mestmäcker commentary is more, however, than a source of authority within the German competition law system; it also influences the structures and dynamics of that system. Here

23. In this context it is difficult to convey the term "Wissenschaft" in English. In many contexts it can be translated as "scientific," but the narrower concept of "science" in English renders that translation awkward in this context. As a consequence, "scholarly" appears less problematic. For discussion of the concepts of "Wissenschaft" and "science," see Shils, supra n. 7, at 100-28.

24. For some insightful comments on the concept of dominant opinion, see Markesinis, "Conceptualism, Pragmatism and Courage: A Common Lawyer Looks at Some Judgments of the German Federal Court," 34 Am. J. Comp. L. 349, 352-54 (1974).

25. I do not, of course, suggest that any particular claim in the commentary necessarily represents the dominant opinion on the issue, but merely that claims included there automatically tend to be associated with the collective opinion of a leading group within the community and thus with community opinion itself. 
again the self-reflexive character of the relationships among authority, community and commentary are important: the system's structures and dynamics shape the roles of the commentary, and the commentary, in turn, helps to shape the system. ${ }^{26}$

The commentary influences, for example, the distribution of power within the system. To appear as an author signals one's membership in a particularly selective and authoritative group within the system's leadership community. The commentary's authority confers value on this membership; it becomes a highly visible badge of status within the community.

This, in turn, enhances the power within the system of those who control access to membership - the editors. In choosing members they are distributing a valuable "good" within the system. One result is to reinforce the personal authority of the editors by encouraging authors and potential authors to provide something in return - perhaps increasing the likelihood that an editor will be invited to a seminar or private discussion, perhaps even yielding a more sympathetic reading of a particular doctrinal position. Because of the already high status of those involved, these influences are likely to be minor and subliminal in any particular situation, but their cumulative effect on many decisions over a long period of time is likely to influence the way the system operates.

These aspects of the commentary's role also support the maintenance and influence of doctrinal "schools." For example, the Mestmäcker "school" is very influential in German competition law. Professor Mestmäcker has been a leading expert in the area for more than four decades, having been, for example, the first president of the Monopoly Commission, the group of five "experts" created by legislation in 1973 and charged with independent review of important developments within German competition law. His "Schüler" (students) ${ }^{27}$ include many of the other academic leaders in the area such as his co-author Ulrich Immenga, also a recent president of the Monopolies Commission, and Wernhard Möschel, the current law professor on the commission and the author of probably the leading treatise on competition law. ${ }^{28}$ The Immenga/Mestmäcker commen-

26. Günther Teubner's work on law as an autopoietic system has valuable applications here, although I am not aware that he has applied his analysis in this type of context. For an application that has some similarities to the one I am discussing here, see Teubner, "Regulatory Law: Chronicle of a Death Foretold," 1 Soc. \& Leg. Stud. 451 (1992).

27. The term "Schüler" denotes a far more intensive relationship than does its English translation. To be the Schüler of a particular professor in the German legal system means that one has written his doctoral dissertation and/or his Habilitation (a book-length research project required, in principle, of all candidates to be professors within the German university system) for that professor. This generally means many years of working for the professor as an assistant and a close professional relationship that frequently continues throughout one's professional life.

28. See supra n. 8. 
tary reinforces the authority of this school by associating it with the dominant commentary in the area, and it reinforces the school's cohesiveness by providing a unifying task for at least some of its members-namely, the writing and editing of the Immenga/Mestmäcker commentary.

A commentary can influence not only the structures of power within the system, but also its operations. The Immenga/ Mestmäcker commentary tends, for example, to shape the discourse of the system. It has become the natural starting point for discussions of cornpetition law issues within this powerful authorship group. Given the prominence of the authors within the leadership community, it tends to play that same role within the leadership community and within the system as a whole: As the starting-point for discussion and thought, it tends to shape the formation of issues and the patterns of analysis and thus the decisions reached.

Another example involves the flow of information within the system - e.g., what information is made available to whom and who listens to whom. In strengthening the cohesiveness of the authorship group, the Inmenga/Mestmäcker commentary tends to influence this flow, for relationships within the group form channels through which information tends to flow - while also being shaped in the process of transmission. Where, as here, such channels carry and structure information among leading academics, top officials of the Federal Cartel Office and the key judges within the system, they inevitably influence the most important decisions within the system. In addition, access to these flows of information becomes valuable in its own right - both to others within the system and to those outside the system who seek to predict the outcome of such decisions (such as corporations and their legal advisors).

\section{Two Ways of Reading}

Where a book about law plays a significant role in the system it describes, reading (or reviewing) it without reference to that dimension may miss much of importance. Moreover, the value of "system" reading increases with the importance of that role. ${ }^{29}$ This type of reading can reveal not only unsuspected dimensions of the text, but also much about the system that might otherwise remain undetected.

System reading "sees" more in the text than does content reading alone - it reveals more information. It perceives the text as not merely descriptive - a statement about the law, but as an influence within the legal system. The book's descriptive content acquires additional - often normative - dimensions, and for the reader who

29. "System reading" is not a wholly satisfactory term for the type of reading I am discussing, but I have found no other single adjective that conveys as much information. 
recognizes those dimensions the text of the book becomes a richer source of information.

Reading the text from a systemic perspective can also provide, as we have seen, information about the system, and the information it reveals is frequently not available in other materials. As we have seen, for example, the Immenga/Mestmäcker commentary plays significant roles in the dynamics of power within the leadership community of German competition law. For most observers (i.e., system outsiders) this dimension of the system is likely to be opaque - the information may be known to insiders, but it is not likely to be discussed in the conventional literature. One value of system reading is, therefore, that it encourages questions that are likely to reveal this type of information.

These two ways of reading are complementary, each enriching the other. The reader seeks accurate and useful information, and thus she necessarily reads the text for its content. Where the text plays a role in the system, she can use system reading to expand the information she receives and improve its quality by seeing more of its dimensions. Similarly, the value of system reading frequently depends on content reading, because in a particular encounter with a reference work the reader is seeking information about the interplay of text and system. She wants to know what "the law" is, but she also wants - or should want - to know how the text actually works within the system. In short, we can understand the text better by understanding the system, and we can understand the system better by understanding the role of the text in it.

The potential value of system reading enhances the importance of book reviews - and increases the burdens on reviewers, because readers often will have limited capacity to read a particular text from a systemic perspective. This will be particularly likely in the case of foreign observers and non-specialists. System reading requires knowledge of the system, and readers will vary greatly in the amount of information they have about a particular system and thus their ability to read systemically. Consequently, many will have to depend on reviews for the insights into the system that make system reading possible.

The Immenga/Mestmäcker commentary provides a valuable example of a book that is an extraordinary source of information as well as a force within the system of law which it describes. To read its contents is to acquire authoritative and valuable data about German competition law and insights into its system; to understand the commentary's roles in that system provides even more. 